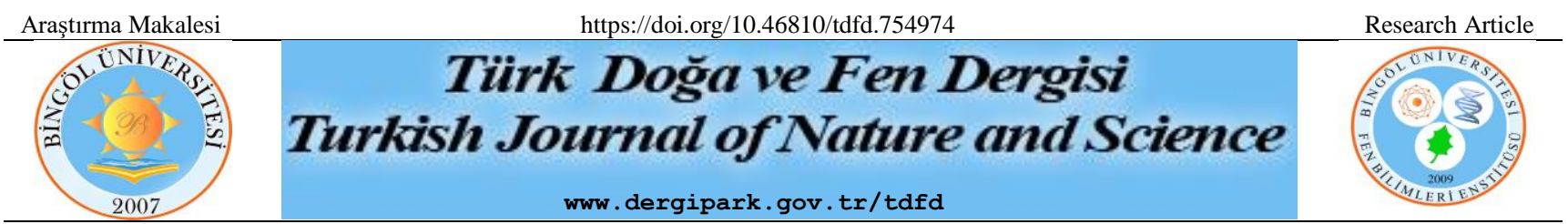

\title{
Çukurova Koşullarında Bazı Kum Darısı (Panicum miliaceum L.) Genotiplerinin Agromorfolojik ve Ot Kalite Özellikleri Üzerine Bir Araştırma
}

\author{
Zeyni DAĞTEKİN ${ }^{1}$, Rüştü HATIPPOĞLU ${ }^{2 *}$, Celal YÜCEL ${ }^{3}$ \\ ${ }^{1}$ Konya Gıda ve Tarım Üniversitesi Tarım ve Doğa Bilimleri Fakültesi, Konya/Türkiye \\ ${ }^{2}$ Çukurova Üniversitesi Ziraat Fakültesi Tarla Bitkileri Bölümü, Adana/Türkiye \\ ${ }^{3}$ Şırnak Üniversitesi Ziraat Fakültesi Tarla Bitkileri Bölümü, Şırnak/Türkiye \\ Zeyni DAĞTEKİN ORCID No: 0000-0003-3342-3117 \\ Rüştü HATİPOĞLU ORCID No:0000-0002-7977-0782 \\ Celal YÜCEL ORCID No:0000-0001-6792-5890 \\ *Sorumlu Yazar: rhatip@cu.edu.tr
}

(Alınış: 19.06.2020, Kabul: 14.10.2020, Online Yayınlanma: 23.10.2020)

\begin{abstract}
Anahtar
Kelimeler

Kum dar1,

Genotip,

Agromorfoloji,

Ot Kalitesi
\end{abstract}

\begin{abstract}
Öz: $\mathrm{Bu}$ araştırma kum darısı (Panicum miliaceum L.) türüne ait 11 genotipin Çukurova koşullarındaki performanslarını belirlemek amacıyla yapılmıştır. Kum darısı genotipleri 2017 yılı yetiştirme mevsiminde Doğu Akdeniz Tarımsal Araştırma Enstitüsü arazisinde sıra arası $70 \mathrm{~cm}$ sıra üzeri $10 \mathrm{~cm}$ olacak şekilde $5 \mathrm{~m}$ uzunluğundaki sıralara birer sıra halinde ekilmiştir. İncelenen genotiplerde; \%50 çiçeklenmeye erişme süresi, bitki boyu $(\mathrm{cm})$, kardeş sayısı /bitki, yaprak sayıs1/ana sap, kuru ot verimi/bitki, yaprak oranı (\%), kuru maddede ham protein oranı (\%), ADF oranı $(\%)$, NDF oranı $(\%)$, fosfor oranı $(\%)$, kalsiyum oranı $(\%)$, magnezyum oranı $(\%)$ ve potasyum oranı (\%) incelenmiştir. İncelenen kum darısı genotiplerinde $\% 50$ çiçeklenmeye erişme süresinin 35-60 gün, bitki boyunun 72,2-142,8 cm, bitki başına kardeş sayısının 5,4-42,2 adet, ana sapta yaprak sayısının 7,2-16 adet, yeşil ot veriminin 112,2-790,2 g, kuru ot veriminin 28,6-165,9 g, yaprak oranının \% 19,7-51,9, ham protein oranının \%16,3-20,5, ADF oranının \%28,7-36,3, NDF oranının \%60-70,6, P oranının \%0,373-0,434, Ca oranının \%0,58-0,824, Mg oranının \%0,2700,393 ve $\mathrm{K}$ oranının \%3,174-3,964 arasında değiştiği saptanmıştır. 11 nolu ve IPM 2875 kodlu genotip yüksek verim ve orta derecede ot kalitesi ile dikkati çekmiştir.
\end{abstract}

\section{Agro-Morphological and Hay Quality Characteristics of Some Proso Millet (Panicum miliaceaum L.) Genotypes Under Cukurova Conditions}

\section{Keywords} Proso millet, Genotype, Agromorphology Hay quality

\begin{abstract}
This research was conducted to determine performances of 11 genotypes of proso millet during the growing season of 2017 under Cukurova conditions. Seeds of each genotypes of proso millet were sown in a $5 \mathrm{~m}$ row with a row spacing of $70 \mathrm{~cm}$ and $10 \mathrm{~cm}$ intra- rowspacing. In the field experiment, agromorphological and hay quality traits of the genotypes such as days to flowering, plant height, number of tillers per plant, number of leaves in the main stem, green herbage yield, hay yield, leaf ratio, crude protein, ADF, NDF, P, Ca, Mg and $\mathrm{K}$ contents of dry matter were studied. The mentioned characteristics of the proso millet genotypes varied from 35 to 60 days, from 72.2 to $142.8 \mathrm{~cm}$, from 5.4 to 42,2 tillers, from 7.2 to 16 leaves, from 112.2 to 790.2 $\mathrm{g}$, from 28.6 to $165.9 \mathrm{~g}$, from 19.7 to $51.9 \%$, from 16.3 to $20.5 \%$, from 28.7 to $36.3 \%$, from 60 to $70.6 \%$, from 0.373 to $0.434 \%$, from 0.58 to $0.824 \%$, from $\% 0.270$ to $0.393 \%$ and from 3.174 to $3.964 \%$, respectively. The genotype with genotype number 11 and genotype code IPM 2875 was the most promising genotype with high yield and middle hay quality
\end{abstract}

\section{GİRIŞ}

Ülkemizde ekonomik bir hayvancılık için hayvancılık işletmelerinin kaliteli kaba yem gereksiniminin karşılanması gerekir. Bunun için de çayır-meraların ıslahı, yem bitkisi üretim alanlarının artırılması, ucuz ve alternatif diğer kaba yem kaynaklarının hayvansal üretime kazandırılması ve kaliteli kaba yem üretim tekniklerinin üreticilere aktarılması gerekmektedir $[1,2]$ Kaba yemin en önemli kaynaklardan birisi olan yem bitkileri tarımı, bitkisel ve hayvansal üretimin de 
sigortası konumunda olup, sürekli ve güvenli kaba yem üretiminin en önemli yoludur [3, 4]

Mera tesisinde karışımda yer alabilecek türler belirlenirken yemin eksik olduğu dönemlerde yeşil otlatma dönemini uzatabilecek, ek yemleme dönemini azaltacak türlerin karışımda yer alması gerekmektedir [5]. Buna göre serin mevsim yem bitkileri ile birlikte sıcak mevsim yem bitkilerinin karışımlarda yer almasıyla otlatmada yeşil yem dönemi uzatılabilecektir.

Akdeniz ikliminin hakim olduğu bölgelerde ortalama sıcaklık Haziran ayı itibariyle $25^{\circ} \mathrm{C}^{\prime}$ yi geçmekte ve bu dönem içerisinde serin mevsim yem bitkisi türleri uzun süre dormant duruma geçmektedir. Hayvancı̆̆ın söz konusu dönemdeki kaba yem gereksiniminin karşılanması için sıcak mevsimde kaba yem üretebilecek yembitkisi türlerinin yetiştirilmesi gerekir. Ülkemizin Akdeniz ikliminin hakim olduğu bölgelerde bugüne kadar yürütülen araştırmalarda; serin dönemde yetiştirilebilecek bir ve çok yıllık yem bitkileri türlerinin saptanmasına yönelik araştırmalar sürdürülmüş olmasına karşılık, sıcak dönemde yetiştirilebilecek yem bitkisi türleri mısır ve sorgum ile sınırlı kalmıştır.

Akdeniz ikliminin hâkim olduğu bölgelerde sıcak ve kurak yaz döneminde yetiştirilebilecek alternatif yem bitkileri grubundan birisi de darılardır. Darılar, dünyanın kurak ve yarı kurak tropik bölgelerindeki milyonlarca insanın temel gıdasıdır ve çoğu Asya, Afrika ülkesinde ve Avrupa'nın bazı bölgelerinde tarımı yapılmaktadır.

Darılar ülkemizin batı bölgelerinde buğday hasadından sonra ikinci ürün olarak yetiştirilmektedir. Sicak yaz aylarında hızlı bir gelişme ile kısa zamanda kaliteli kaba yem üretirler $[6,7]$.

$\mathrm{Bu}$ araştırmada, Akdeniz ikliminin hâkim olduğu bölgelerde yaz döneminde yetiştirilebilecek bir yıllık sıcak mevsim buğdaygil yem bitkisi türlerinden olan kum dar1 (Panicum miliaceum L.) 'nın bazı genotiplerinin Çukurova koşullarındaki performansları araştırılmıştır.

\section{MATERYAL VE METOT}

$\mathrm{Bu}$ araştırmada Uluslararası Yarı Kurak Tropik Bölge Tarımsal Araştırma Enstitüsünden (ICRISAT) temin edilen 11 adet kum darı (Panicum miliaceum L.) genotipi materyal olarak kullanılmıştır.

$\mathrm{Bu}$ araştırma, Doğu Akdeniz Tarımsal Araştırma Enstitüsü Araştırma ve Uygulama Alanında, HaziranEkim 2017 döneminde yürütülmüştür.

Araştırmanın yürütüldüğü Doğu Akdeniz Tarımsal Araştırma Enstitüsü deneme alanı toprakları Arıklı toprak serisi olup, 0-15 ve $15-30 \mathrm{~cm}$ derinlikten alınan toprak örneklerinde yapılan analizler sonucunda; $\mathrm{pH}$ 'nın 7,38-7,51 arasinda (hafif alkali), toplam tuz \%0,24-0,27 (hafif tuzlu), $\mathrm{N} \% 0,11-0,18$ (yeterli), organik karbon (OC) \% 0,80-0,90 (çok az), fosfor $0,70-0,78 \mathrm{mg} / \mathrm{kg}$ (çok az), kireç içeriği $\left(\mathrm{CaCO}_{3}\right) \% 33,5-34,0$ (çok kireçli), kum;
\%24-28, silt \% 42-43, kilin ise \%30-33 arasında değiștiği ve toprak tekstür sınıfının killi-tın (CL) yapısında olduğu saptanmıştır.

Denemenin yürütüldüğü Doğu Akdeniz Tarımsal Araştırma Enstitüsü'nün bulunduğu Adana ilinde tipik Akdeniz iklimi hakim olup,, kışları 1lık ve yağışlı, yaz dönemi sıcak ve kurak geçmektedir. Adana Meteoroloji İl Müdürlüğü kayıtlarına göre aylık ortalama sıcaklık değerleri deneme yılında uzun yıllar ortalamasından daha yüksek seyretmiştir. Araştırmanın yürütüldüğü dönemde deneme alanına düşen toplam yağış miktarı $(116,7 \mathrm{~mm})$ uzun yıllar ortalamasına $(140,3)$ göre daha düşük olmuştur. Deneme y1lında aylara göre nispi nem değeri Haziran ve Eylül ayı dışında uzun yıllar ortalamalarından daha düşük seyretmiştir.

Denemede; kum dar1 (Panicum miliaceum L.) genotipleri sira aras $70 \mathrm{~cm}$ ve sira üzeri $10 \mathrm{~cm}$ olacak şekilde $5 \mathrm{~m}$ uzunluğundaki sıralara birer sıra halinde ekilmiştir. Ekim işlemi 15 Haziran 2017 tarihinde yapılmıştır. Ekimden önce deneme alanı pullukla sürülmüştür. Daha sonra goble-disk çekilerek kesekler parçalanmıştır. Sonra parselleme yapılıp, ekimden önce parsellerin tesviyesi tırmıkla yapılarak, taş ve kesekler uzaklaştırılmış ve el markörü çekilerek çiziler oluşturulmuştur. Deneme parsellerinde dekara $25 \mathrm{~kg}$ saf azot, $10 \mathrm{~kg} \mathrm{P}_{2} \mathrm{O}_{5}$ ve $10 \mathrm{~kg} \mathrm{~K} 2 \mathrm{O}$ olacak şekilde gübreleme yapılmıştır. Azotun yarısı ile fosfor ve potasyumun tamamı ekimle birlikte tabana, azotun diğer yarısı da bitkiler 20-25 cm boya ulaştığında sıra aralarına uygulanmıştır. Ekim, tavlı toprağa yapılmış, çıkış için yağmurlama sulama yapılmıştır. Bitkilerin çıkışından sonra damla sulama sistemi ile sulamaya devam edilmiştir.

Deneme parsellerinde; her genotipe ait parselde parseldeki bitkilerin \%50'sinin çıktığ çiçeklendiği tarih arasındaki süre $\% 50$ çiçeklenme süresi olarak kaydedilmiştir. Ayrıca, her parselde tesadüfi olarak seçilen 5 bitkide toprak yüzeyinden bitkinin en uç noktasına kadar olan kısım bitki boyu olarak kaydedilmiştir. Denemede hasat bitkilerin salkım çıkarma döneminde genotiplere bağlı olarak 24.07.210716.08.2107 tarihleri arasında yapılmıştır. Hasat zamanında her genotipe ait parselde bitkilerin salkım çıkardığı dönemde tesadüfi olarak seçilen 5 bitki toprak yüzeyinden biçilmiş ve her bitkiden hasat edilen ot ayrı ayrı tartılmıştır. Her genotipte yeşil ot verimi belirlenen 5 bitkide kardeş sayısı ve ana saptaki yaprak sayısı sayılmıştır. Her genotipte yeşil ot verimi belirlenen 5 bitkide saplar üzerindeki yapraklar yaprak kınından koparılmış ve saplar ve yapraklar ayrı ayrı tartılmıştır. Her bitkide yeşil ağırlığı belirlenen yaprak ve saplar etüvde $70{ }^{\circ} \mathrm{C}$ ' de kurutularak ayrı ayrı kuru ağırlıkları belirlenmiştir. Her bitkide saptanan kuru yaprak ağırlığı ve kuru sap ağırlığının toplamı söz konusu bitki için kuru ot verimi olarak hesaplanmıştır. Her genotipte kuru yaprak ve sap ağırlıkları belirlenen 5 bitkinin her birinde kuru yaprak ağırlığı kuru ot verimine oranlanarak söz konusu bitki için yaprak oranı hesaplanmıştır. 
Her genotipin 5 bitkisinin her birinin kuru yaprak ve sapları $1 \mathrm{~mm}$ 'lik elekten geçecek şekilde öğütüldükten sonra, ögütülmüş yaprak ve sap örneklerinden alınan 5 'er gram örnek $105^{\circ} C^{\prime}$ ye ayarlı etüvde 24 saat kurutulduktan sonra desikatörde soğutularak hassas terazide tartılmış ve örneklerin kuru madde içerikleri \% olarak belirlenmiştir. Her genotipe ait 5 bitkinin her birine ait $1 \mathrm{~mm}$ 'lik elekten geçecek şekilde ögütülmüş yaprak ve sap örneklerinde C-0904FE-Hay and Fresh Forage kalibrasyonu kullanilarak The Foss XDS NIRS (Near Infrared Reflectance Spectroscopy) analiz cihaziyla ham protein, ADF, NDF, fosfor, kalsiyum, magnezyum ve potasyum oranları saptanmıştır. Her bitkinin yaprak ve sapı için saptanan söz konusu değerler kuru madde oranlarından yararlanılarak yaprak ve saptaki kuru madde esasına göre hesaplanmış ve söz konusu kalite özelliklerinin yaprak ve saptaki oranları ile yaprak oranından yararlanılarak tüm bitkinin kuru maddesindeki ham protein oranı hesaplanmıştır.

Her genotipten elde edilen verilere 5 tekrarlamalı tesadüf parselleri deneme desenine [8] göre varyans analizi uygulanmıştır. İstatistiksel olarak önemli çıkan özellik ortalamaları Duncan testi ile karşılaştırılmıştır. İncelenen özellikler arasındaki ikili ilişkiler korelasyon katsayıları belirlenerek saptanmıştır.

\section{BULGULAR}

\section{1. \% 50 Çiçeklenme Süresi (gün)}

İncelenen genotiplerde \% 50 çiçeklenmeye kadar geçen süre 35 ile 60 gün arasında değişmiştir (Tablo 1). 3 nolu IPM 2270 genotipi geçciliği ile göze çarpmıştır. Söz konusu genotip toprak yüzüne çıkıştan yaklaşık 2 ay sonra çiçeklenmiştir. Buna karşılık 1, 2, 5, 7 ve 8 nolu genotipler 1 ay, diğer genotipler ise 1.5 ayda çiçeklenme dönemine erişmişlerdir.

Genotiplerin \% 50 çiçeklenmeye erişme süreleri ile ilgili bulgular, kum darının ekimden 36-45 günde çiçeklenmeye eriştiğini bildiren Kaume [9] ve Tran[10]'nin bildirişleri, Hindistan'da 833 kum darı genotipinde çiçeklenmeye erişme süresinin 26-50 gün arasında değiştiğini saptayan Upadhyaya ve ark.[11] ve Nepal'de 42 kum darı genotipinde çiçeklenmeye erişme süresinin 28-57 gün arasında değiştiğini saptayan Ghimire ve ark. [12]'nın bulguları ile uyumludur.

\subsection{Bitki Boyu (cm)}

İncelenen kum darısı genotiplerinde ortalama bitki boyu $72,2 \mathrm{~cm}$ ile $142,8 \mathrm{~cm}$ arasında değişmiş ve bu değişimin istatistiksel olarak önemli olduğu ortaya çıkmıştır (Tablo 1). Üç nolu ve IPM 2270 kodlu kum darısı genotipi $142,8 \mathrm{~cm}$ bitki boyu ile 1 nolu kum darısı genotipi dışındaki incelenen diğer genotiplerden istatistiksel olarak önemli derecede daha yüksek bitki boyu göstermiştir. 7 nolu ve IPM 2635 kodlu kum darıs1 genotipi ise $72,2 \mathrm{~cm}$ bitki boyu ile incelenen diğer kum darıs1 genotiplerine göre istatistiksel olarak önemli derecede daha düşük bitki boyu göstermiştir.
Araştırmada saptanan kum darısı genotiplerindeki bitki boyu değerleri; kum darısının 30-100 cm ye kadar boylanabildiğini bildiren Baltensperger ve ark.[13]' nin bildirişleri, Hindistanda inceledikleri 833 kum dar1 genotipinde bitki boyunun 20-133 cm arasinda değiștiğini saptayan Upadhyaya ve ark. [11]'nın bulguları ve Nepalde 42 kum darısı gemotipinde bitki boyunun 80-155 cm arasında değiştiğini saptayan Ghimire ve ark. [12]'nın bulguları ile uyumludur.

\subsection{Kardeş Sayısı (adet/bitki)}

İncelenen kum darısı genotiplerinde ortalama kardeş sayısı 5,4 ile 42,2 arasında değișmiş ve bu değişimin istatistiksel olarak önemli olduğu ortaya çıkmıştır (Tablo 1).

10 nolu ve IPM 1586 kodlu kum darıs1 genotipi 42,2 kardeş sayısı ile incelenen diğer genotiplerden istatistiksel olarak önemli derecede daha yüksek kardeşlenme göstermiştir. 2 nolu ve IPM 2867 kodlu kum darısı genotipi ise 5,4 kardeş sayısı ile 3 nolu kum darısı genotipi dişındaki incelenen diğer genotiplere göre istatistiksel olarak önemli derecede daha düşük kardeşlenme göstermiştir.

Araştırmada kum darısı genotiplerinde saptanan kardeş sayısı değerleri; 30 ülke orjinli kum darı genotiplerinde kardeş sayısının 1-32 arasında değiştiğini saptayan Upadhyaya ve ark. [11]'nın bulguları ile uyumludur.

\subsection{Yaprak Sayısı (adet/ana sap)}

İncelenen genotiplerde ortalama ana sapta yaprak sayıs 7,2 ile 16,0 arasında değişmiş ve bu değişimin istatistiksel olarak önemli olduğu ortaya çıkmıştır (Tablo 1). 6 nolu ve IPM 2797 kodlu genotip ana sapta 16,0 adet yaprak ile 7 nolu genotip dışındaki incelenen diğer genotiplerden istatistiksel olarak önemli derecede daha yüksek ana sapta yaprak sayısı göstermiştir. 4 nolu ve IPM 2230 kodlu genotip ise ana sapta 7,2 yaprak sayıs1 ile incelenen diğer genotiplere göre istatistiksel olarak önemli derecede daha düşük ana sapta yaprak sayısı göstermiştir.

\subsection{Yeșil Ot Verimi (g/bitki)}

İncelenen kum darısı genotiplerinde bitki başına yeşil ot verimi 112,2 ile 790,2 $\mathrm{g}$ arasında değişmiş ve bu değişimin istatistiksel olarak önemli olduğu ortaya çıkmıștır (Tablo 1). 11 nolu ve IPM 2875 kodlu kum darısı genotipi bitki başına 790,2 g yeşil ot verimi ile incelenen diğer genotiplerden istatistiksel olarak önemli derecede daha yüksek yeşil ot verim vermiştir. 7 nolu ve IPM 2635 kodlu kum darıs1 genotipi ise 112,2 g bitki başına yeşil ot verimi ile incelenen diğer kum darısı genotiplerine göre istatistiksel olarak önemli derecede daha düşük bitki başına yeşil ot verimi vermiştir. 
Tablo 1. Kum Darısı Genotiplerinde İncelenen Özelliklerle İlgili Ortalama Değerler

\begin{tabular}{|c|c|c|c|c|c|c|c|c|c|c|c|c|c|c|}
\hline GK & $\% 50 C ̧$ & BB & KS & YS & YOV & KOV & YO & HPO & ADF & NDF & $\mathbf{P}$ & $\mathrm{Ca}$ & Mg & $\mathbf{K}$ \\
\hline IPM 2897 & 36 & $139,2 \mathrm{ab}^{1}$ & $9,2 \mathrm{e}^{1}$ & $10,2 \mathrm{e}^{1}$ & $320,8 \mathrm{c}^{1}$ & $77,4 \mathrm{c}^{1}$ & $48,7 \mathrm{~b}^{1}$ & $20,2 \mathrm{ab}^{1}$ & $28,7 \mathrm{e}^{1}$ & $60,0 \mathrm{~d}^{1}$ & $0,416 b c^{1}$ & $0,824 \mathrm{a}^{1}$ & $0,393 \mathrm{a}^{1}$ & 3,845 a-d \\
\hline IPM 2867 & 36 & $135,8 \mathrm{~b}$ & $5,4 \mathrm{f}$ & $10,4 \mathrm{e}$ & $215,8 \mathrm{~g}$ & $47,3 \mathrm{~g}$ & $35,2 d$ & $16,3 \mathrm{e}$ & $33,6 \mathrm{~b}$ & $64,8 \mathrm{c}$ & $0,395 \mathrm{de}$ & 0,607 ef & 0,315 ef & $3,552 \mathrm{f}$ \\
\hline IPM 2270 & 60 & $142,8 \mathrm{a}$ & 8,0 ef & $10,8 \mathrm{de}$ & $289,6 \mathrm{~d}$ & $68,1 \mathrm{e}$ & $35,5 \mathrm{~d}$ & $19,5 \mathrm{bc}$ & $33,9 \mathrm{~b}$ & $65,3 \mathrm{bc}$ & $0,392 \mathrm{de}$ & $0,707 \mathrm{~b}$ & $0,324 \mathrm{c}-\mathrm{e}$ & $3,528 \mathrm{f}$ \\
\hline IPM 2230 & 43 & $88,6 \mathrm{e}$ & $16,6 \mathrm{~d}$ & $7,2 \mathrm{f}$ & $254,0 \mathrm{f}$ & $63,1 \mathrm{f}$ & $36,2 d$ & $16,5 \mathrm{e}$ & $36,3 \mathrm{a}$ & $70,6 \mathrm{a}$ & $0,419 b$ & $0,580 \mathrm{~g}$ & $0,319 \mathrm{~d}-\mathrm{f}$ & $3,907 \mathrm{ab}$ \\
\hline IPM 2171 & 35 & $89,6 \mathrm{e}$ & $17,8 \mathrm{~d}$ & $10,8 \mathrm{c}-\mathrm{e}$ & 136,0 I & $31,5 \mathrm{j}$ & $23,7 \mathrm{f}$ & $18,3 \mathrm{~d}$ & $32,7 \mathrm{bc}$ & $65,6 \mathrm{bc}$ & $0,402 \mathrm{~cd}$ & $0,648 \mathrm{~d}$ & $0,306 \mathrm{f}$ & $3,907 \mathrm{ab}$ \\
\hline IPM 2797 & 49 & $127,2 \mathrm{c}$ & $24,6 \mathrm{c}$ & $16,0 \mathrm{a}$ & $266,6 \mathrm{e}$ & $72,7 d$ & $31,2 \mathrm{e}$ & $16,8 \mathrm{e}$ & $32,7 b c$ & $66,8 \mathrm{bc}$ & 0,381 ef & $0,689 \mathrm{c}$ & $0,308 \mathrm{f}$ & $3,174 \mathrm{~g}$ \\
\hline \begin{tabular}{|l|l|} 
IPM 2635 \\
\end{tabular} & 37 & $72,2 \mathrm{~g}$ & $23,2 \mathrm{c}$ & $14,6 \mathrm{ab}$ & $112,2 \mathrm{j}$ & $28,6 \mathrm{j}$ & $19,7 \mathrm{~h}$ & $20,5 \mathrm{a}$ & $31,4 \mathrm{~cd}$ & $65,2 \mathrm{bc}$ & $0,404 \mathrm{~cd}$ & $0,597 \mathrm{f}$ & \begin{tabular}{|l|}
$0,329 \mathrm{~cd}$ \\
\end{tabular} & $3,817 \mathrm{~b}-\mathrm{d}$ \\
\hline IPM 2858 & 36 & $130,0 \mathrm{c}$ & $9,0 \mathrm{e}$ & $9,4 \mathrm{e}$ & $481,2 \mathrm{~b}$ & $95,2 \mathrm{~b}$ & $51,9 \mathrm{a}$ & $20,2 \mathrm{ab}$ & $30,0 \mathrm{de}$ & $65,2 b c$ & $0,423 \mathrm{ab}$ & $0,713 \mathrm{~b}$ & $0,365 \mathrm{~b}$ & $3,865 \mathrm{a}-\mathrm{c}$ \\
\hline IPM 2093 & 43 & $89,2 \mathrm{e}$ & $29,0 \mathrm{~b}$ & $13,2 \mathrm{bc}$ & $178,2 \mathrm{~h}$ & $39,0 \mathrm{~h}$ & $21,2 \mathrm{~g}$ & $19,2 \mathrm{c}$ & $34,1 \mathrm{~b}$ & $67,4 \mathrm{~b}$ & $0,397 \mathrm{~d}$ & $0,457 \mathrm{~h}$ & $0,270 \mathrm{~h}$ & $3,964 \mathrm{a}$ \\
\hline IPM 1586 & 43 & $82,2 \mathrm{f}$ & $42,2 \mathrm{a}$ & $13,0 \mathrm{~b}-\mathrm{d}$ & $113,6 \mathrm{c}$ & $35,5 \mathrm{I}$ & $21,1 \mathrm{~g}$ & $18,0 \mathrm{~d}$ & $31,1 \mathrm{~cd}$ & $66,7 \mathrm{bc}$ & $0,373 \mathrm{f}$ & $0,460 \mathrm{~h}$ & $0,334 \mathrm{c}$ & $3,730 \mathrm{de}$ \\
\hline IPM 2875 & 41 & $121,8 \mathrm{~d}$ & $18,0 \mathrm{~d}$ & 11,6 c-e & $790,2 \mathrm{a}$ & $165,9 \mathrm{a}$ & $38,2 \mathrm{c}$ & $17,5 \mathrm{~d}$ & $34,5 \mathrm{~b}$ & $66,6 \mathrm{bc}$ & $0,434 \mathrm{a}$ & $0,614 \mathrm{e}$ & $0,286 \mathrm{~g}$ & $3,762 \mathrm{c}-\mathrm{e}$ \\
\hline \begin{tabular}{|l|} 
ORT \\
\end{tabular} & 41.7 & 110,78 & 18,4 & 11,5 & 287,1 & 65,8 & 33,0 & 18,4 & 32,6 & 65,5 & 0,403 & 0,627 & 0,323 & 3,711 \\
\hline
\end{tabular}

1)Aynı sütun içerisinde benzer harf ile gösterilen ortalamalar Duncan testine göre $\mathrm{P} \leq 0.05$ hata sinırları içerisinde istatistiksel olarak birbirinden farksızdır.

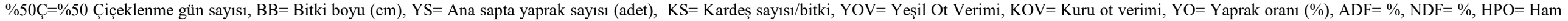
protein içeriği (\%), $\mathrm{P}=$ Fosfor içeriği (\%), $\mathrm{K}=$ Potasyum içeriği (\%),, $\mathrm{Ca}=\mathrm{Ca}$ içeriği (\%), $\mathrm{Mg}=\mathrm{Mg}$ içeriği, G.K=Genotip Kodu 


\subsection{Kuru Ot Verimi (g/bitki)}

İncelenen kum darısı genotiplerinde bitki başına kuru ot verimi 28,6 ile 165,9 $\mathrm{g}$ arasında değişmiş ve bu değişimin istatistiksel olarak önemli olduğu ortaya çıkmıştır (Tablo 1). 11 nolu ve IPM 2875 kodlu kum darısı genotipi bitki başına 165,9 g kuru ot verimi ile incelenen diğer kum darısı genotiplerinden istatistiksel olarak önemli derecede daha yüksek kuru ot verimi vermiştir. 7 nolu ve 2635 kodlu kum darısı genotipi ise bitki başına 28,6 g kuru ot verimi ile incelenen diğer kum darısı genotiplerine göre istatistiksel olarak önemli derecede daha düşük kuru ot verimi göstermiştir.

\subsection{Yaprak Oranı (\%)}

İncelenen kum darısı genotiplerinde ortalama yaprak oranı \%19,7 ile 51,9 arasında değişmiş ve bu değişimin istatistiksel olarak önemli olduğu ortaya çıkmıştır (Tablo 1). 8 nolu ve IPM 2858 kodlu kum darıs1 genotipi $\% 51,9$ yaprak oranı ile incelenen diğer kum darısı genotiplerinden istatistiksel olarak önemli derecede daha yüksek yaprak oranı göstermiştir.

7 nolu ve IPM 2635 kodlu kum darıs1 genotipi ise \%19,7 yaprak oranı ile incelenen diğer genotiplere göre istatistiksel olarak önemli derecede daha düşük yaprak oranı göstermiştir.

\subsection{Kuru Maddede Ham Protein Oranı (\%)}

İncelenen kum darısı genotiplerinde kuru madde de ortalama ham protein oranı \%16,3 ile 20,5 arasinda değişmiş ve bu değişimin istatistiksel olarak önemli olduğu ortaya çıkmıştır (Tablo 1). 7 nolu ve IPM 2635 kodlu kum darıs genotipi \%20,5'lik kuru madde de ortalama ham protein oranı ile 2,3,4,5,6,9,10 ve 11 nolu kum darısı genotiplerinden istatistiksel olarak önemli derecede daha yüksek ham protein oranı ortalamas1 göstermiştir. 2 nolu ve IPM 2867 kodlu kum darıs1 genotipi ise $\% 16,3^{\prime}$ 'lük ham protein oranı ile 4 ve 6 nolu kum darısı genotiplerinin dışında incelenen diğer kum darıs1 genotiplerine göre istatistiksel olarak önemli derecede daha düşük ortalama kuru madde de ham protein oranı göstermiştir. Yapılan araştırmada kum darıs1 genotiplerinde saptanan kuru madde de ham protein oranı değerlerinin, \%11,5 ila 13,0 arasında değiştiğini ve maksimum $\% 17^{`} \mathrm{i}$ olduğunu bildiren Geervani ve Eggum [14] ve kum darı otunun \%4,6$\% 17,6$ ham protein içerdiğini bildiren Tran [10]'ın bildirişleri ile uyumludur.

\subsection{ADF Oranı (\%)}

İncelenen kum darıs1 genotiplerinde ortalama ADF oranı \% 28,7 ile 36,3 arasında değişmiş ve bu değişimin istatistiksel olarak önemli olduğu ortaya çıkmıştır (Tablo 1). 4 nolu ve IPM 2230 kodlu kum darıs1 genotipi \% 36,3 ADF oranı ile incelenen diğer kum darısı genotiplerinden istatistiksel olarak önemli derecede daha yüksek ADF oranı göstermiştir. 1 nolu ve IPM 2897 kodlu kum darısı genotipi ise \%28,7 ADF oranı ile 8 nolu kum darısı genotipleri dışındaki diğer genotiplere göre istatistiksel olarak önemli derecede daha düşük
ADF oranı göstermiş̧tir. Araştırmada saptanan kum darısı genotiplerinin ADF oranı değerleri; Mohajer ve ark[15]'nin üç darı çeşidinde saptadıkları \%26,75-33,72 arsında değişen ADF oranları, Berhane ve ark [16]'nın yaptıkları araştırmada kum darısı için saptadıkları \%33,7-37,4 arasında değişen ADF oranları ve kum darıda ADF oranının \%12,9-48,9 arasında değiştiğini bildiren Tran [10]'in bildirişi ile uyumludur.

\subsection{NDF Oranı (\%)}

İncelenen kum darıs1 genotiplerinde ortalama NDF oranı \%60,0 ile 70,6 arasında değişmiş ve bu değişimin istatistiksel olarak önemli olduğu ortaya çıkmıştır (Tablo 1). 4 nolu ve IPM 2230 kodlu kum darısı genotipi $\% 70,6$ NDF oranı ile incelenen diğer kum darısı genotiplerinden istatistiksel olarak önemli derecede daha yüksek NDF oranı göstermiştir. 1 nolu ve IPM 2897 kodlu kum darısı genotipi ise \%60 NDF oranı ile incelenen diğer kum darısı genotiplerine göre istatistiksel olarak önemli derecede daha düşük NDF oranı göstermiştir.

Araştırmada saptanan kum darısı genotiplerinin NDF oranı değerleri; Tran[10]'ın kum darısı için bildirdiği \%33,6-81,6 arasında değişen NDF değerleri ile uyumludur.

\subsection{Fosfor (P) Oranı (\%)}

İncelenen kum darıs1 genotiplerinde ortalama fosfor oranı \%0,373 ile \%0,434 arasında değişmiş ve bu değişimin istatistiksel olarak önemli olduğu ortaya çıkmıştır (Tablo 1). 11 nolu ve IPM 2875 kodlu kum darıs1 genotipi $\% 0,434$ fosfor oranı ile incelenen diğer kum darısı genotiplerinden istatistiksel olarak önemli derecede daha yüksek fosfor oranı göstermiştir. 10 nolu ve IPM 1586 kodlu kum darıs genotipi ise $\% 0,373$ fosfor oranı ile incelenen diğer kum darısı genotiplerine göre istatistiksel olarak önemli derecede daha düşük fosfor oranı göstermiştir. Araştırmada kum darısı genotiplerinde saptanan fosfor oranı değerleri; Tran [10]'ın kum darısı kuru maddesi için bildirdiği $\% 0,05-\% 0,22$ değerlerinin üzerindedir. $\mathrm{Bu}$ duruma neden olarak, araştırmalar arasındaki ekolojik koşullar, genotipler, yetiştirme teknikleri ve fosfor içeriği belirleme yöntemleri açısından farklılıklar gösterilebilir.

\subsection{Kalsiyum (Ca) Oranı (\%)}

İncelenen kum darıs genotiplerinde ortalama kalsiyum oranı \%0,457 ile \%0,824 arasında değişmiş ve bu değişimin istatistiksel olarak önemli olduğu ortaya çıkmıştır (Tablo 1). 1 nolu ve IPM 2897 kodlu kum darısı genotipi \%0,824 kalsiyum oranı ile incelenen diğer kum darıs1 genotiplerinden istatistiksel olarak önemli derecede daha yüksek kalsiyum oranı göstermiştir. 9 nolu ve IPM 2093 kodlu kum darıs genotipi ise \%0,457 kalsiyum oranı ile incelenen diğer kum darısı genotiplerine göre istatistiksel olarak önemli derecede daha düşük kalsiyum oranı göstermiştir. Araştırmada kum darısı genotipleri için saptanan kalsiyum oranı değerleri; Tran [10]'1n kum darı kuru ot kuru maddesi için bildirdiği \%0,13-0,79 kalsiyum oranı değerleri ile uyumludur. 


\subsection{Magnezyum (Mg) Oranı (\%)}

İncelenen kum darısı genotiplerinde ortalama magnezyum oranı $\% 0,270$ ile 0,393 arasında değişmiş ve bu değişimin istatistiksel olarak önemli olduğu ortaya çıkmıştır (Tablo 1). 1 nolu ve IPM 2897 kodlu kum darıs1 genotipi \%0,393 magnezyum oranı ile incelenen diğer kum darısı genotiplerinden istatistiksel olarak önemli derecede daha yüksek magnezyum oranı göstermiştir. 9 nolu ve IPM 2093 kodlu kum darısı genotipi ise \%0,270 magnezyum oranı ile incelenen diğer kum darısı genotiplerine göre istatistiksel olarak önemli derecede daha düşük magnezyum oranı göstermiştir. Araştırmada kum darısı genotipleri için saptanan magnezyum oranı değerleri Tran [10]'1n kum darısı ot kuru maddesi için bildirdiği \%0,300 - \%0,400 değerleri ile uyumludur.

\subsection{Potasyum (K) Oranı (\%)}

İncelenen kum darıs1 genotiplerinde ortalama potasyum oranı \%3,174 ile 3,964 arasında değişmiş ve bu değişimin istatistiksel olarak önemli olduğu ortaya çıkmıştır (Tablo 1). 9 nolu ve IPM 2093 kodlu kum darıs1 genotipi \%3,964 potasyum oranı ile 2,3,6,10 ve 11 nolu kum darısı genotiplerinden istatistiksel olarak önemli derecede daha yüksek potasyum oranı göstermiştir. 6 nolu ve IPM 2797 kodlu kum darıs1 genotipi ise $\% 3,174$ potasyum oranı ile incelenen diğer kum darısı genotiplerine göre istatistiksel olarak önemli derecede daha düşük potasyum oranı göstermiştir. Araştırmada saptanan potasyum oranı değerleri Tran [10]'ın kum darısı kuru maddesi için bildirdiği \%0,19-\% 2,92 değerlerinden oldukça yüksektir. Bu duruma neden olarak, araştırmalar arasındaki ekolojik koşullar, genotipler, yetiştirme teknikleri ve potasyum içeriği belirleme yöntemleri açısından farklılıklar gösterilebilir.

\subsection{5. İncelenen özellikler Arasındaki İlişkiler}

Kum darısı genotiplerinde incelenen özellikler arasındaki ikili ilişkiler için saptanan korelasyon katsayıları Tablo 2'de verilmiştir.

Çizelgede izlendiği gibi, bitki boyu ile kardeş sayısı, NDF oranı ve $\mathrm{K}$ oranı arasında çok önemli olumsuz ilişki, bitki boyu ile yeşil ot verimi, yaprak oranı, kuru ot verimi, Ca oranı ve $\mathrm{Mg}$ oranı arasında çok önemli olumlu ilişki olduğu saptanmıştır.

Kardeş sayısı ile ana sapta yaprak sayısı ve NDF oranı arasında çok önemli olumlu ilişki, kardeş sayısı ile yaprak oranı, yeşil ot verimi, kuru ot verimi, NDF oranı, $\mathrm{P}$ ve Ca oranı arasında çok önemli olumsuz ilişki, kardeş sayısı ile magnezyum oranı arasında ise önemli olumlu ilişki olduğu ortaya çıkmıştır.

Ana sapta yaprak sayısı ile yeşil ot verimi ve fosfor oranı arasında çok önemli olumsuz ilişki, yaprak sayısı ilse K içeriği arasında ise önemli olumsuz ilişki olduğu ortaya çıkmıştır.

Yaprak oranı ile yeşil ot ve kuru ot verimi, P, Ca ve Mg içeriği arasında çok önemli olumlu ilişki, yaprak oranı ile NDF oranı arasında çok önemli olumsuz ilişki olduğu saptanmıştır.

Yeşil ot verimi ile kuru ot verimi ve kuru maddenin $\mathrm{P}$ içeriği arasında çok önemli olumlu ilişki, yeşil ot verimi ile kuru maddenin Ca içeriği arasında ise önemli olumlu ilişki olduğu saptanmıştır.

Kuru ot verimi ile P içeriği arasında çok önemli, kuru ot verimi ile $\mathrm{Ca}$ içeriği arasında ise önemli olumlu ilişki olduğu ortaya çıkmıştır.

Kuru maddenin ham protein içeriği ile NDF ve ADF içeriği arasında çok önemli olumsuz ilișki, kuru maddenin ham protein oranı ile $\mathrm{K}$ ve $\mathrm{Mg}$ içeriği arasında çok önemli, Ca içeriği arasında önemli olumlu ilişki olduğu ortaya çıkmıştır.

Ot kuru maddesinin ADF içeriği ile NDF içeriği arasında çok önemli olumlu ilişki, ADF içeriği ile Ca ve $\mathrm{Mg}$ içeriği arasında çok önemli olumsuz ilişki olduğu saptanmıştır.

Ot kuru maddesinin NDF içeriği ile $\mathrm{Ca}$ ve $\mathrm{Mg}$ içeriği arasında çok önemli olumsuz ilişki olduğu saptanmıştır.

Ot kuru maddesinin $\mathrm{P}$ içeriği ile $\mathrm{K}$ içeriği arasında çok önemli, P içeriği ile Ca içeriği arasında önemli olumlu ilişki olduğu saptanmıştır.

Ot kuru maddesinin $\mathrm{Ca}$ içeriği ile $\mathrm{Mg}$ içeriği arasında çok önemli olumlu ilişki olduğu saptanmıştır.

\section{SONUÇ}

Yukarıda açıklanan araştırma sonuçlarına dayanılarak, kum darısının Çukurova'nın sulanan koşullarında yaz döneminde bölge hayvancılığının kaliteli kaba yem ihtiyacının karşılanması amacıyla başarıyla yetiştirilebileceği, incelenen genotipler arasında 11 nolu IPM 2875 kodlu genotipin ümitvar olduğu, türün bölge koşullarında başarılı bir şekilde yetiştirilebilmesi için yetiştirme tekniklerinin saptanmasına yönelik araştırmaların yürütülmesi gerektiği sonucuna varılmıştır.

NOT: Zeyni DAĞTEKİN'in Yüksek Lisans Tez çalışmasından üretilmiştir 
Tablo 2. Kumdarı Bitkisinde Incelenen Özellikler Arasındaki Korelasyon Katsayıları

\begin{tabular}{|c|c|c|c|c|c|c|c|c|c|c|c|c|}
\hline & KS & YS & YO & YOV & KOV & HPO & ADF & NDF & $\bar{P}$ & $\mathbf{K}$ & $\mathbf{C a}$ & Mg \\
\hline BB & $-0,686^{* * *}$ & $-0,167$ & $0,754 * *$ & $0,498 * *$ & $0,513 * *$ & $-0,027$ & $-0,135$ & $-0,473 * *$ & 0,125 & $-0,399 * *$ & $0,708^{* *}$ & $0,301 *$ \\
\hline KS & & $0,468^{* *}$ & $-0,694 * *$ & $-0,339^{*}$ & $-0,297 *$ & $-0,064$ & $-0,010$ & $0,408^{* *}$ & $-0,459 * *$ & 0,041 & $-0,707 * *$ & $-0,306^{*}$ \\
\hline YS & & & $-0,490 * *$ & $-0,200$ & $-0,164$ & 0,060 & $-0,051$ & 0,104 & $-0,454 * *$ & $-0,363^{*}$ & $-0,207$ & $-0,231$ \\
\hline YO & & & & $0,626^{* * *}$ & $0,618^{* *}$ & 0,120 & $-0,248$ & $-0,523 * *$ & $0,549^{* * *}$ & 0,071 & $0,731 * *$ & $0,550^{* *}$ \\
\hline YOV & & & & & $0,988 * *$ & $-0,045$ & 0,080 & $-0,163$ & $0,642 * *$ & 0,068 & $0,317^{*}$ & $-0,020$ \\
\hline KOV & & & & & & $-0,096$ & 0,090 & 0,123 & $0,596^{* * *}$ & $-0,005$ & $0,340 *$ & $-0,013$ \\
\hline HPO & & & & & & & $-0,581 * *$ & $-0,597 * *$ & 0,135 & $0,381 * *$ & $0,279^{*}$ & 0,441 ** \\
\hline ADF & & & & & & & & $0,793^{* *}$ & 0,043 & $-0,048$ & $-0,379 * *$ & $-0,645^{* * *}$ \\
\hline NDF & & & & & & & & & $-0,198$ & $-0,070$ & $-0,614 * *$ & $-0,659 * *$ \\
\hline $\mathbf{P}$ & & & & & & & & & & $0,487 * *$ & $0,321^{*}$ & 0,131 \\
\hline $\mathbf{K}$ & & & & & & & & & & & $-0,238$ & 0,138 \\
\hline $\mathrm{Ca}$ & & & & & & & & & & & & $0,587^{* * *}$ \\
\hline
\end{tabular}

$\mathrm{BB}=\mathrm{Bitki}$ boyu $(\mathrm{cm}) . \mathrm{YS}=$ Ana sapta yaprak sayısı (adet). KS= Kardeş sayısı/bitki. $\mathrm{YOV}=\mathrm{Yeşil} \mathrm{Ot} \mathrm{Verimi.} \mathrm{KOV}=\mathrm{Kuru}$ ot verimi. $\mathrm{YO}=\mathrm{Yaprak}$ oranı $(\%) . \mathrm{ADF}=\%$. NDF= \%. $\mathrm{HPO}=\mathrm{Ham}$ protein içeriği $(\%)$. $\mathrm{P}=$ Fosfor içeriği (\%). $\mathrm{K}=$ Potasyum içeriği (\%), Ca= Ca içeriği (\%), Mg= Mg içeriği, *) $\mathrm{P} \leq 0.05$ hata sınırları içinde önemli; **) $\mathrm{P} \leq 0.01$ hata sınırları içinde önemli 


\section{KAYNAKLAR}

[1] Serin Y, Tan M. Yem Bitkileri Kültürüne Giriş. Atatürk Üniversitesi Ziraat Fakültesi Yayınları, No: 206, 2001

[2] Yolcu H, Tan M. Ülkemiz yem bitkileri tarımına genel bir bakış. Tarım bilimleri Dergisi 2008;14 (3): 303-312.

[3] Açıkgöz E. Yem Bitkileri (3. Bask1). Uludağ üniversitesi güçlendirme vakfi, yayın No 182 , 2001.

[4] Açıkgöz E, Hatipoğlu R, Altınok S, Sancak C, Tan A, Uraz D. Yem bitkileri üretimi ve sorunlari. Türkiye Ziraat Mühendisliği VI. Teknik Kongresi, 2005 ; 503-518.

[5] Altın M, Gökkuş A, Koç A. Çayır Mera Islahı. Tarım ve Köyişleri Bakanlığı, Tarımsal Üretim ve Geliştirme Genel Müdürlüğü, Çayır Mera Yem Bitkileri ve Havza Geliştirme Daire Başkanlığı, Ankara, 468s, 2005.

[6] Asgharipour M, Tavssoli A. Effect of irrigation with wastewater and foliar fertilizer application on some forage characteristics of foxtailmillet (Setaria italica). International Journal of Plant Physiology and Biochem, 2012; 3(3): 34-42.

[7] Serin Y, Tan M. Buğdaygil Yembitkileri. Atatürk Üniv. Yay. No: 859, Ziraat Fak. Yay. No: 334, Ders Kit. No: 81, Erzurum, 263 s., 2014.

[8] Yurtsever N. Deneysel İstatistik Metotları. Tarım ve Köy İşleri Bakanlığı Tarımsal Araştırmalar Genel Müdürlüğü Toprak Gübre ve Su Kaynakları Merkez Araştırma Enstitüsü Yayınları Genel Yayın No: 121 Teknik Yayın No 56,800s, 2011.

[9] Kaume RN. Panicum miliaceum L.. Record from Protabase. Brink, M. \& Belay, G. (Editors). PROTA (Plant Resources of Tropical Africa / Ressources végétales de l'Afrique tropicale), Wageningen, Netherlands, 2006.

[10] Tran G. Proso millet (Panicum miliaceum), forage. Feedipedia, a programme by INRA, CIRAD, AFZ and FAO. https://www.feedipedia.org/node/409 Last updated on September 1, 2017, 23:02

[11] Upadhyaya HD, Sharma S, Gowda CLL, Reddy VG, Singh S. Developing proso millet (Panicum miliaceum L.) core collection using geographic and morpho-agronomic data. Crop \& Pasture Science 2011; 62: 383-389.

[12] Ghimire KH, Joshi BK, Dhakal R, Sthapit BR. Diversity in proso millet (Panicum miliaceum L.) landraces collected from Himalayan mountains of Nepal. Genet Resour Crop Evol 2018; 65:503-512.

[13] Baltensperger DD. Progress with proso, pearl and other millets. Trends in new crops and new uses 2002, 100-103.

[14] Geervani P, Eggum BO. Nutrient composition and protein quality of minor millets. Plant Foods Hum Nutr. 1989; 39: 201-208.

[15] Mohajer S, Ghods H, Taha RM, Talati A.Effect of different harvest time on yield and forage quality of three varieties of common millet (Panicum miliaceum). Scientific Research and Essays, 2012; 7(34), 3020-3025.

[16] Berhane G, Eik LO, Tolera A. Chemical composition and in vitro gas production of vetch (Vicia sativa) and some browse and grass species in northern Ethiopia. African Journal of Range and Forage Science, 2006; 23(1): 69-75. 